\title{
Differential susceptibility to TRAIL of normal versus malignant human urothelial cells
}

\author{
LP Steele $^{1}$, NT Georgopoulos ${ }^{1,2}$, J Southgate ${ }^{2}$, PJ Selby ${ }^{1}$ and \\ LK Trejdosiewicz ${ }^{* 1}$ \\ 1 Institute of Molecular Medicine, Epidemiology \& Cancer Research, St James's \\ University Hospital, Leeds, UK \\ 2 Jack Birch Unit for Molecular Carcinogenesis, Department of Biology, \\ University of York, York, UK \\ * Corresponding author: LK Trejdosiewicz, Lymphoepithelial Interactions \\ Laboratory, Cancer Research Building, Institute of Molecular Medicine, \\ Epidemiology \& Cancer Research, St James's University Hospital, Leeds LS9 \\ 7TF, UK. Tel: + 44(0) 113206 5266; Fax: + 44(0) 113242 9886; \\ E-mail: I.k.trejdosiewicz@leeds.ac.uk
}

Received 06.4.05; revised 16.11.05; accepted 16.11.05; published online 13.1.06 Edited by GM Cohen

\begin{abstract}
Comparing normal human urothelial (NHU) cells to a panel of six representative urothelial cell carcinoma (UCC)-derived cell lines, we showed that while TRAIL receptor expression patterns were similar, susceptibility to soluble recombinant crosslinked TRAIL fell into three categories. 4/6 carcinoma lines were sensitive, undergoing rapid and extensive death; $\mathrm{NHU}$ and $253 \mathrm{~J}$ cells were partially resistant and HT1376 cells, like normal fibroblasts, were refractory. Both normal and malignant urothelial cells underwent apoptosis via the same caspase-8/9-mediated mechanism. Rapid receptor downregulation was a mechanism for evasion by some UCC cells. TRAIL resistance in malignant urothelial cells was partially dependent on FLIP $\mathrm{L}$ and was differentially mediated by p38 ${ }^{\text {MAPK }}$, whereas in normal cells, resistance was mediated by NF- $\kappa \mathrm{B}$. Importantly, extensive killing of UCC cells could be induced using noncrosslinked TRAIL after prolonged exposure, with no damage to their homologous, normal urothelial cell counterparts.

Cell Death and Differentiation (2006) 13, 1564-1576.

doi:10.1038/sj.cdd.4401846; published online 13 January 2006
\end{abstract}

Keywords: apoptosis; TRAIL; bladder cancer; urothelium; human

Abbreviations: CAPE, caffeic acid phenethyl ester; $\mathrm{CHX}$, cycloheximide; DcR, decoy receptor; DISC, death-inducing signaling complex; DR, death receptor; FADD, Fas-associated death domain protein; FLIP, FADD-like IL-1 $\beta$-converting enzymelike inhibitory protein; His, poly-histidine (protein tag); IAP, inhibitor of apoptosis protein; IFN, interferon; IL, interleukin; KSFM, keratinocyte serum-free medium; NF, nuclear factor; $\mathrm{NHU}$, normal human urothelial; PI, propidium iodide; siRNA small interfering RNA; TGF, transforming growth factor; TRAIL, TNF-related apoptosis-inducing ligand; UCC, urothelial cell carcinoma

\section{Introduction}

Tumor necrosis factor (TNF)-related apoptosis-inducing ligand (TRAIL) is a member of the TNF family capable of inducing apoptosis following ligation of one or both of the TRAIL death receptors, TRAIL-R1 (DR4) and TRAIL-R2 (DR5), ${ }^{1,2}$ and assembly of a death-inducing signaling complex (DISC). ${ }^{3}$ Although some components of the DISC remain unknown, recruitment of both the Fas-associated death domain (FADD) and of caspase-8 is necessary for TRAILinduced apoptosis. ${ }^{4}$ TRAIL can also bind to two decoy receptors, TRAIL-R3 (decoy receptor 1, DcR1) and TRAILR4 (DcR2), which lack a functional cytoplasmic death domain and consequently are incapable of transducing apoptotic signals. Although decoy receptors may serve to protect normal cells from TRAIL-induced apoptosis, ${ }^{5}$ the exact nature of their function remains poorly understood. Recent evidence suggests that, rather than occurring at the level of the receptor, TRAIL resistance may be mediated via intracellular mechanisms. ${ }^{6}$

TRAIL was initially thought to exhibit a high degree of tumor cell specificity in vitro and in vivo, ${ }^{7}$ although subsequent findings showed that some malignant cells are resistant ${ }^{8,9}$ and more recent data details significant killing of normal epithelial cell types by certain recombinant TRAIL preparations. ${ }^{10-12}$ Of the four preparations reported, three consist of the extracellular domain of TRAIL fused at the amino terminus to a leucine zipper, ${ }^{5}$ a FLAG polypeptide epitope $\operatorname{tag}^{13}$ or a polyhistidine (His) tag, ${ }^{5}$ respectively. The fourth is an untagged soluble trimeric TRAIL preparation optimized for zinc content, which has been shown to have an antitumor effect in an animal model without causing hepatotoxicity. ${ }^{14}$ The potency of soluble TRAIL preparations appears to be a function of ligand crosslinking, as His-tagged TRAIL (His-TRAIL) is thought to form multimeric aggregates capable of overcoming the resistance of some normal cell types ${ }^{5}$ and crosslinking FLAG-tagged TRAIL with anti-FLAG antibody enhances its apoptotic capability. ${ }^{15}$ These findings have important implications for the use of TRAIL as a cancer therapeutic and highlight the need to assess the toxicity of monomeric versus multimeric TRAIL preparations against normal and malignant cells of the same tissue and cell-type derivation.

Although urothelial cell carcinoma (UCC) of the urinary bladder is a common malignancy, patterns of TRAIL receptor expression and susceptibility of UCC cells to TRAIL-induced apoptosis have not been studied extensively ${ }^{16,17}$ and nothing is known of the responses of normal human urothelial (NHU) cells to TRAIL. We have developed a highly reproducible and robust system for the culture of $\mathrm{NHU}$ cells, ${ }^{18,19}$ the validity and relevance of which as a model for normal urothelial cell behavior is evidenced by findings that the cells can be induced to express genes specific to urothelial terminal differentiation. ${ }^{20}$ Thus, our aims were to assess the apoptotic susceptibility of normal and malignant human urothelial cells as a 
function of TRAIL receptor expression and ligand crosslinking, together with a determination of the molecular mechanisms involved in any differential apoptotic susceptibilities or resistance to TRAIL-mediated apoptosis. To these ends, we used a representative panel of UCC-derived cell lines that have been extensively characterized in the literature and which accurately recapitulate the grade and stage of the tumors of origin in vitro and in vivo. ${ }^{21,22}$

\section{Results}

\section{TRAIL receptor expression}

NHU- and UCC-derived cells showed broadly similar patterns of TRAIL receptor surface expression (Figure 1a). NHU cells expressed TRAIL-R1 and TRAIL-R2, but no TRAIL-R3 (DcR1) and very low levels of TRAIL-R4 (DcR2). In all, 5/6 of the UCC cell lines were positive for TRAIL-R1, although expression was low in 253J and undetectable in VM-CUB-3 cells. TRAIL-R2 was expressed by all UCC-derived lines, being highest in the anaplastic EJ and 253J, and lowest in the well-differentiated RT4 and HT1376 cells. NHU cells expressed levels of TRAIL-R2 comparable to EJ and 253J cells. Neither TRAIL-R3 nor TRAIL-R4 was detectable on any UCC-derived line (Figure 1a). Jurkat and HFF control cell lines both expressed TRAIL-R2 at levels comparable to NHU cells, with no detectable surface expression of TRAIL-R1 or decoy receptors (Figure 1a).

\section{Cytokine regulation of TRAIL receptor expression}

Although many TNFR family members are upregulated by proinflammatory cytokines, we found that neither archetypal proinflammatory (e.g. IFN $\gamma$ ) nor anti-inflammatory (e.g. IL-4) cytokines were able to induce significant upregulation of any of the TRAIL receptors, although they did induce upregulation of other TNFR members. ${ }^{23}$ Expression of TRAIL-R1 and TRAIL-R2 was unchanged overall, or underwent very small changes, and there was no evidence of de novo DcR expression by any of the UCC lines (Supplementary Table).

\section{Differential apoptotic susceptibilities of urothelial cells to TRAIL}

The cell lines tested fell into three categories according to apoptotic response to His-TRAIL: sensitive (RT4, RT112, VMCUB-3, EJ and Jurkat), partially resistant (NHU and 253J) and refractory (HT1376 and HFF) (Figure 1b).

His-TRAIL induced rapid and extensive apoptosis in the sensitive cell lines, as evidenced by phase-contrast microscopy, Annexin V/propidium iodide (PI) and caspase-3/7 activation assays (Supplementary Figure 1), typically with up to $80 \%$ cell death at $6 \mathrm{~h}$. The sensitivity of the highly anaplastic EJ line was comparable to that of the positive-control Jurkat cells (Figure 1b). TRAIL-blocking antibody completely abrogated the killing (not shown).

NHU cells showed a moderate dose-related degree of sensitivity to His-TRAIL up to $100 \mathrm{ng} / \mathrm{ml}$ (Figure $1 \mathrm{~b}$ ) and concentrations above $100 \mathrm{ng} / \mathrm{ml}$ did not result in further killing (not shown). 253J cells did not undergo more than $20 \%$
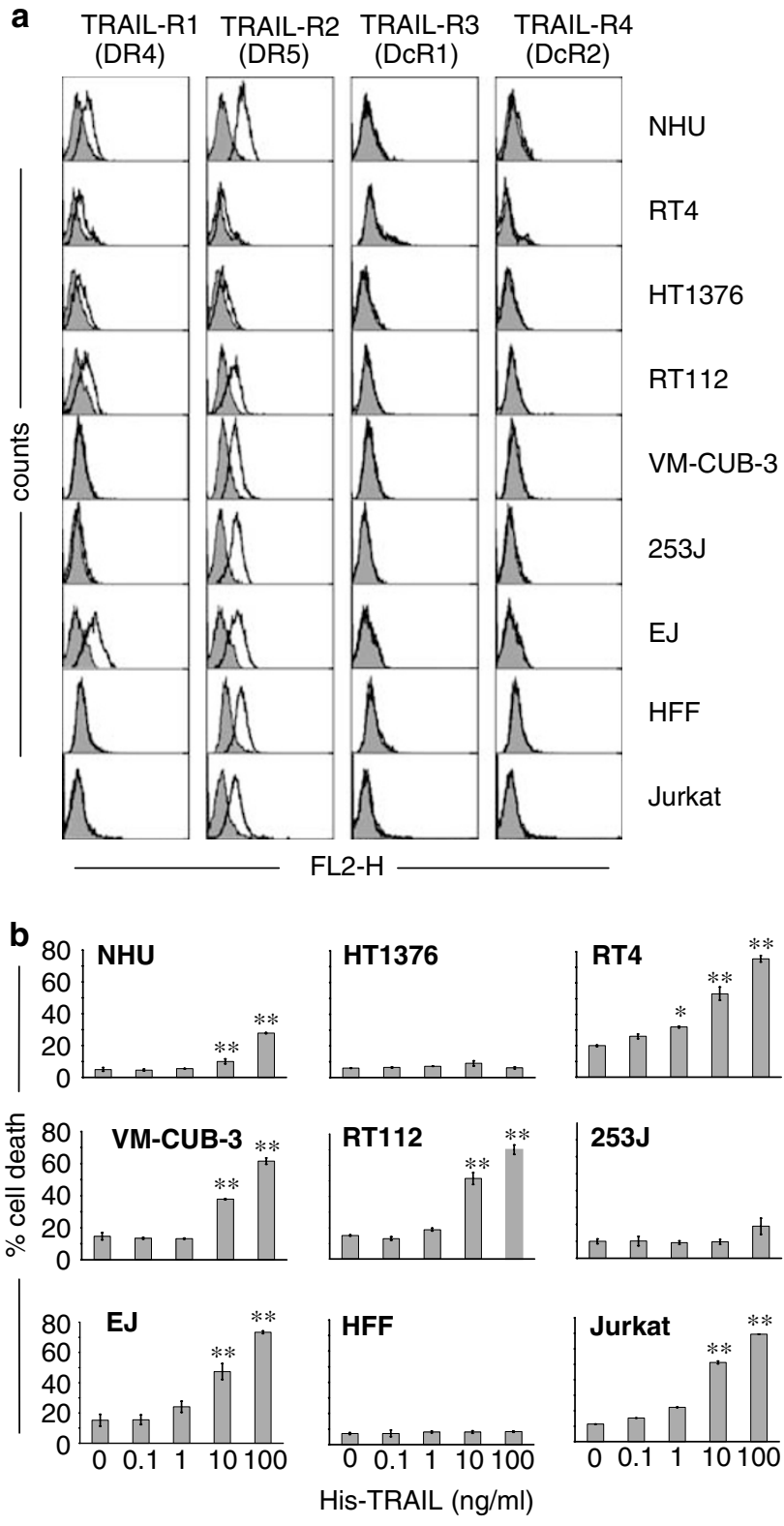

Figure 1 TRAIL receptor expression and apoptotic susceptibility of normal and malignant human urothelial cells. (a) Expression of receptors TRAIL-R1-4 by urothelial cells was assessed by flow cytometry using $10 \mu \mathrm{g} / \mathrm{ml}$ primary antibody as indicated, followed by PE-conjugated secondary antibody (open histograms). Negative controls (secondary antibody alone; filled histograms) were included to determine background fluorescence. Results are expressed as $\log _{10}$ fluorescence (FL-2) intensity. Histogram plots are representative of at least three independent experiments. (b) NHU and UCC cells were seeded in six-well plates, cultured for $24 \mathrm{~h}$ and incubated with His-TRAIL (0-100 $\mathrm{ng} / \mathrm{ml}$ ) for $6 \mathrm{~h}$. Apoptosis was assessed by Annexin V/PI labeling. Bars represent means ( \pm S.D.) of percentage apoptotic/dead cells of duplicate wells and are representative of at least three independent experiments. ${ }^{*}$ Indicates $P<0.01$ and ${ }^{* *}$ represents $P<0.001$, respectively, by ANOVA with Dunnett post-test correction

apoptosis, whereas HT1376 cells were completely resistant, as were the normal fibroblasts, in agreement with other reports. $^{24}$

Thus, normal urothelial cells, unlike normal fibroblasts, showed a degree of sensitivity to His-TRAIL, although 
susceptibility to TRAIL-induced apoptosis in UCC-derived lines was independent of degree of anaplasty and TRAIL receptor expression levels.

\section{Ligand crosslinking and duration of exposure}

To determine the contribution of crosslinking to the efficacy of soluble TRAIL on malignant versus normal urothelial cells, we used TRAIL tagged with the FLAG polypeptide epitope, with and without a crosslinking anti-FLAG antibody, in addition to His-TRAIL, to compare the responses of three TRAILsensitive UCC-derived cell lines (RT4, RT112 and EJ) with
NHU cells. Crosslinked FLAG-TRAIL was almost as effective as His-TRAIL at inducing apoptosis in NHU and the TRAILsensitive UCC cells (Figure 2a). By contrast, noncrosslinked FLAG-TRAIL did not induce any apoptosis in NHU cells, even at $100 \mathrm{ng} / \mathrm{ml}$. The apoptotic susceptibility of UCC lines to FLAG-TRAIL was considerably reduced when crosslinker was omitted (Figure 2a).

Owing to the reduced efficacy of the noncrosslinked preparation, we examined the effects of prolonged exposure. $\mathrm{NHU}$ cells remained refractory, even at $18 \mathrm{~h}$ (Figure $2 \mathrm{~b}$ ). By contrast, noncrosslinked FLAG-TRAIL induced high levels of death in TRAIL-sensitive UCC lines and in Jurkat cells,
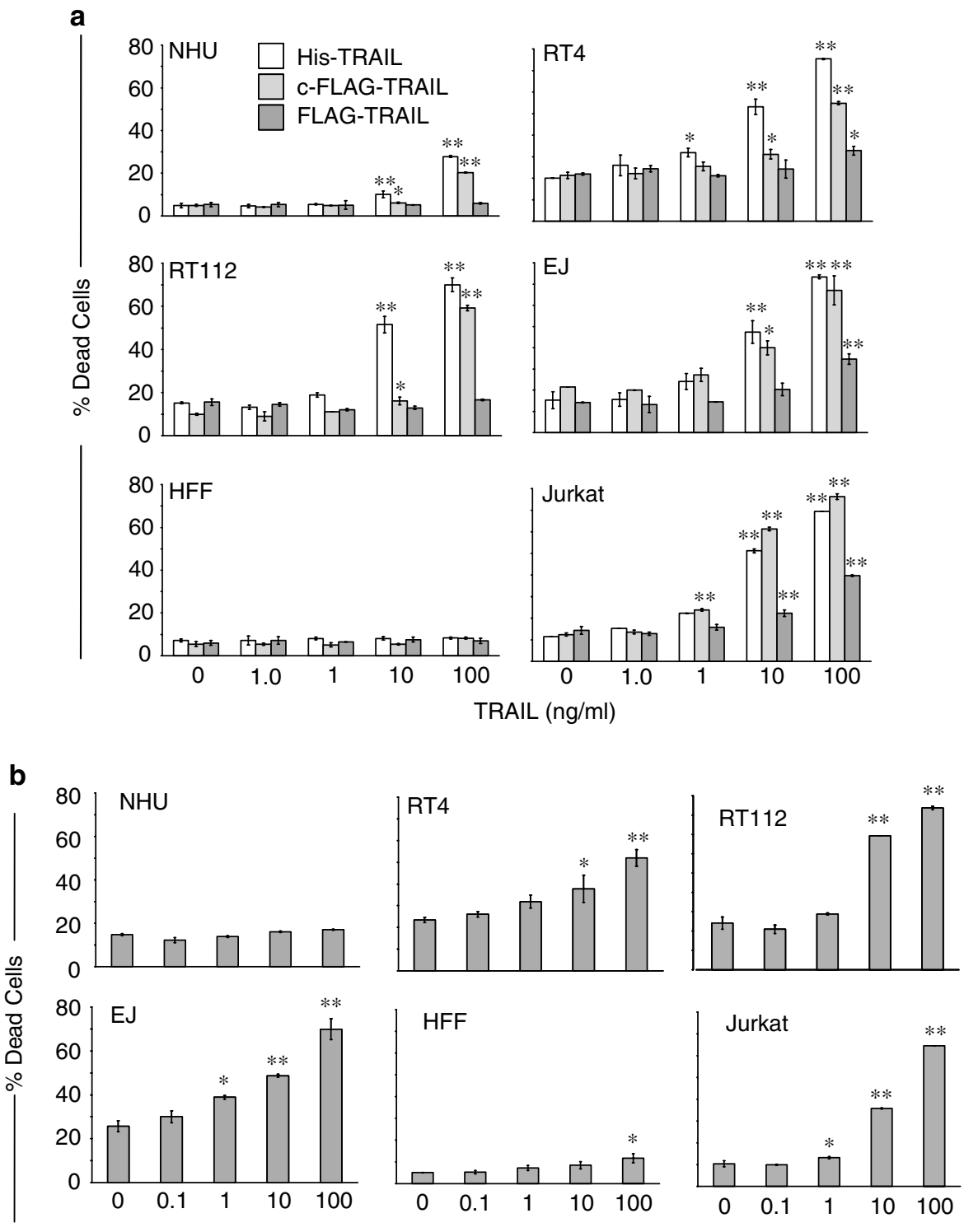

FLAG-TRAIL (ng/ml)

Figure 2 Effect of degree of ligand crosslinking on TRAIL-induced apoptosis. (a) NHU and UCC cells were treated for $6 \mathrm{~h}$ with control medium or His-TRAIL (open bars), FLAG-TRAIL crosslinked by $2 \mu \mathrm{g} / \mathrm{ml}$ anti-FLAG antibody (c-FLAG-TRAIL, pale bars) or FLAG-TRAIL alone (dark bars) at the concentrations indicated. Apoptosis was assessed by flow cytometry using Annexin V-FITC/PI labeling. (b) NHU and UCC cells were treated with FLAG-TRAIL alone for $18 \mathrm{~h}$ at the concentrations indicated. Apoptosis was assessed as above. Bars represent means of percentage apoptotic/dead cells ( + S.D.) of duplicate wells and are typical of three independent experiments. ${ }^{*}$ and ${ }^{*}$ indicate $P<0.01$ and $P<0.001$, respectively, by ANOVA with Dunnett post-test correction 
comparable to those observed with $100 \mathrm{ng} / \mathrm{ml}$ of His-TRAIL for $6 \mathrm{~h}$ (cf Figure 1b). As expected, TRAIL-resistant HFF cells remained refractory to FLAG-TRAIL, irrespective of duration of exposure (Figure $2 \mathrm{~b}$ ).

\section{TRAIL receptor involvement in apoptosis and evasion of TRAIL-induced death}

Since TRAIL-R1 and TRAIL-R2 may be differentially involved in transmitting apoptotic signals, ${ }^{15,25}$ we used specific receptor-blocking antibodies. TRAIL-R1 blocking almost completely abrogated TRAIL-mediated killing of EJ (Figure 3a) and NHU cells (not shown), whereas TRAIL-R2 blocking had no effect. The two antibodies were neither additive nor synergistic (Figure 3a). However, TRAIL-R2 blocking inhibited TRAIL-mediated killing of VM-CUB-3 and Jurkat cells (not shown), both of which express only TRAIL-R2. Thus, although His-TRAIL can transmit a proapoptotic signal via either death receptor, it appears to do so preferentially via TRAIL-R1 when this receptor is expressed.

Despite the high susceptibility of some UCC cell lines to TRAIL, it is unknown whether a fraction of cells might survive, and if so, by what mechanism. We therefore exposed urothelial cells to extremely high concentrations of His-TRAIL (up to $1000 \mathrm{ng} / \mathrm{ml}$ ) for an extended period ( $36 \mathrm{~h}$ ) and assessed cell survival by thymidine incorporation assays after withdrawal of TRAIL. By this criterion, few proliferative RT4 or RT112 cells survived, whereas significant precursor uptake was observed in EJ cells (Figure $3 \mathrm{~b}$ ), indicating that a fraction of cells had survived and proliferated. The surviving EJ cells had completely lost expression of both TRAIL-R1 and TRAIL$\mathrm{R} 2$ after $36 \mathrm{~h}$ exposure to His-TRAIL (Figure 3c) without de novo induction of decoy receptors. However, after a further 7 days in the absence of agonist, TRAIL receptor expression had recovered by approximately $50 \%$ (Figure $3 \mathrm{c}$ ). Collectively, these findings imply that some tumor cells may escape TRAIL-mediated apoptosis by downregulation of TRAIL receptors without the need for concomitant induction of DcR expression.

\section{Mechanisms of TRAIL-mediated apoptosis}

As the crosslinked His-TRAIL preparation induced rapid and effective killing in susceptible cell types, this preparation was used for studies aimed to identify the molecular mechanism(s) of susceptibility or partial resistance to TRAIL-mediated apoptosis. In both partially resistant (NHU) and susceptible (EJ) cell types, pan-Caspase (z-VAD-FMK) and caspase-8 (z-IETD-FMK) inhibitors were potent inhibitors of TRAILmediated apoptosis, with lesser effects seen with caspase-9 inhibitor (z-LEHD-FMK) (Figure 4a). These findings suggest that although TRAIL-induced apoptosis principally invokes the cell-extrinsic pathway, there is crosstalk with the cell-intrinsic pathway.

To determine whether TRAIL resistance is mediated via a protein synthesis-dependent mechanism, cells were pretreated with cycloheximide $(\mathrm{CHX})$. $\mathrm{CHX}$ pretreatment did not affect TRAIL receptor expression (data not shown) but augmented the susceptibility of partially resistant cells (Figure $4 \mathrm{~b}$ ) to levels comparable to those of sensitive cells (cf Figure 1b). CHX had no effect on the TRAIL-refractory cells (Figure 4b). In cells where killing was augmented by $\mathrm{CHX}$, HisTRAIL induced high levels of caspase activation following $\mathrm{CHX}$ pretreatment, unlike the minimal activation induced in control cultures (Figure 4c). Thus, the mechanisms of resistance of partially resistant and refractory cells are fundamentally different, with the former relying on active protein synthesis.

\section{Effects of TRAIL on antiapoptotic protein expression}

Antiapoptotic proteins, such as isoforms of FLIP (FADD-like IL-1 $\beta$-converting enzyme-like inhibitory protein) and the IAP (inhibitor of apoptosis) proteins, can mediate TRAIL resistance. $^{26,27}$ In the case of FLIP, FLIP and FLIP isoforms, as well as a $43 \mathrm{kDa}$ cleavage fragment $\left(\mathrm{FLIP}_{43}\right)$, bind to the DISC and block caspase- 8 cleavage and hence activation of the apoptotic cascade. ${ }^{28}$ As no previous studies have investigated how TRAIL regulates the expression of antiapoptotic proteins in human urothelial cells, we determined their expression in normal and malignant cells following treatment with His-TRAIL.

Partially resistant NHU and UCC-derived cell lines expressed baseline levels of FLIP, FLIP $_{S}, I A P-2$ and XIAP (Figure 5a). However, there was no detectable IAP-1 in NHU cells and only very low levels in the UCC-derived lines (not shown). Following treatment with His-TRAIL, NHU cells underwent a rapid loss of FLIP $\mathrm{L}_{\mathrm{L}}$, which was accompanied by the appearance of the $43 \mathrm{kDa}$ FLIP fragment $\left(\mathrm{FLIP}_{43}\right)$, whereas FLIP , IAP-2 and XIAP expression was unchanged (Figure 5a). 253J cells, which are slightly more TRAIL resistant than $\mathrm{NHU}$, exhibited no apparent change in FLIPL

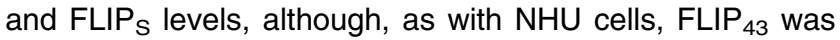
induced after $30 \mathrm{~min}$ of exposure to His-TRAIL. Interestingly, expression of IAP-2 and XIAP increased in the presence of His-TRAIL. By contrast, TRAIL-insensitive HT1376 cells demonstrated no loss of FLIPL, FLIPS, IAP-2 or XIAP, whereas highly sensitive EJ cells showed decreases of FLIP

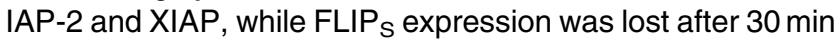
(Figure 5a).

Since $\mathrm{CHX}$ sensitized NHU and 253J cells to TRAILinduced apoptosis, we investigated the effects of $\mathrm{CHX}$ on FLIP, IAP-2 and XIAP expression. Exposure to His-TRAIL following $\mathrm{CHX}$ pretreatment led to decreases in FLIP $\mathrm{L}$ and

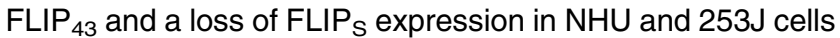
(Figure 5b). However, XIAP was not changed in either cell type and IAP-2 underwent only a small decrease in $253 \mathrm{~J}$ cells. Interestingly, TRAIL-insensitive HT1376 cells also lost expression of FLIP $\mathrm{L}_{\mathrm{L}}$ and FLIP $_{\mathrm{S}}$, although they were not sensitized to apoptosis by $\mathrm{CHX}$ pretreatment. As with $\mathrm{NHU}$ and 253J cells, IAP-2 and XIAP expression was unaffected. These results suggest that the increased susceptibility of $\mathrm{NHU}$ and 253J cells to TRAIL-induced apoptosis following $\mathrm{CHX}$ pretreatment is primarily associated with inhibition of FLIP synthesis. 
The role of NF- $\kappa$ B and $p 38^{\text {MAPK }}$ pathways in TRAIL-induced apoptosis

The $\mathrm{p} 38^{\mathrm{MAPK}}$ and NF- $\kappa \mathrm{B}$ signaling pathways have previously been implicated in apoptotic resistance following receptor ligation by soluble TRAIL. ${ }^{29,30}$ We therefore examined the potential involvement of these pathways in mediating the resistance of partially resistant cells using the highly specific pharmacological inhibitors SB202190 and CAPE, respectively.

a
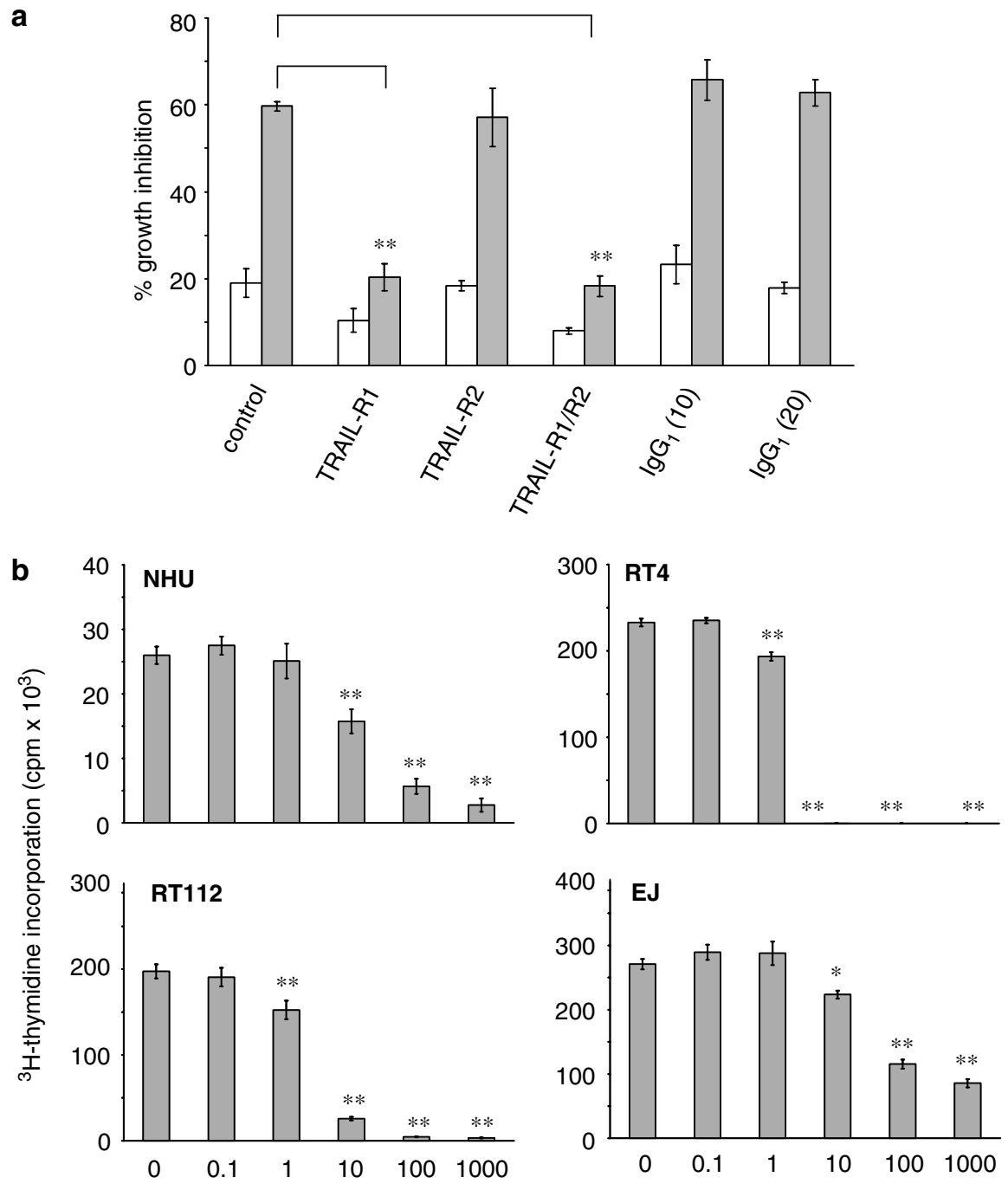

His-TRAIL (ng/ml)

c

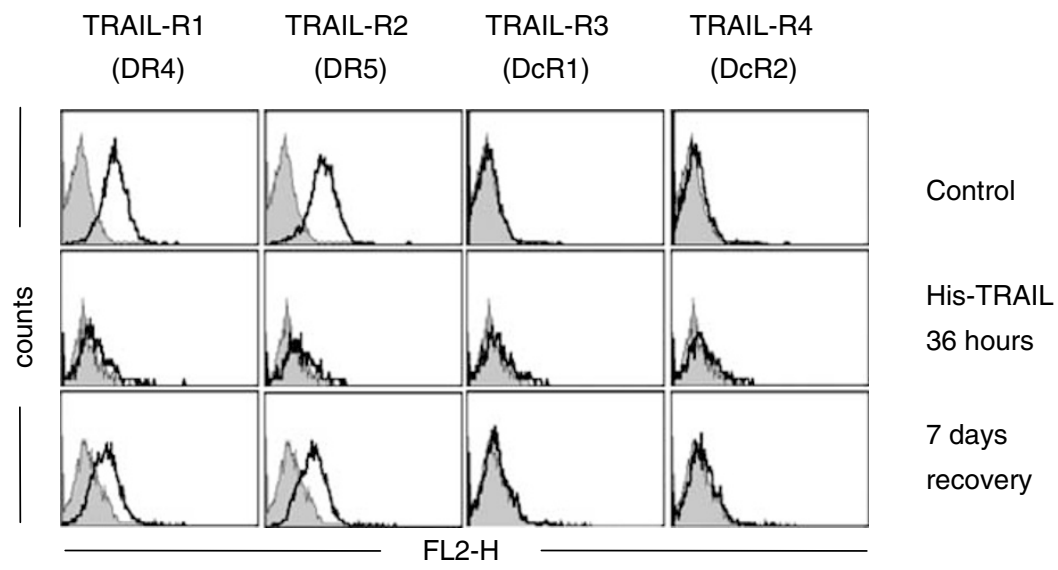


Caffeic acid phenethyl ester (CAPE) has been shown to inhibit translocation of NF- $\kappa$ B. ${ }^{31}$ To confirm the efficacy of CAPE in our system, we showed that pre-treatment of 253J cells with CAPE alone or with a combination of CAPE and TRAIL abrogated translocation of the p50 and p65 nuclear factor (NF)- $\kappa$ B subunits to the nucleus (Supplementary Figure 2). SB202190 specifically inhibits the activity of p38 ${ }^{\mathrm{MAPK}}$ by competing for the ATP-binding sites of the $\alpha$ and $\beta$ isoforms. ${ }^{32}$ This inhibitor has been used very extensively in the literature and has previously been shown to block p38 ${ }^{\mathrm{MAPK}}$-mediated phosphorylation of ATF-2 in our laboratories. ${ }^{33}$

Although both inhibitors dose-dependently increased TRAIL-induced death (Figure $6 \mathrm{a}$ ), inhibition of $\mathrm{NF}-\kappa \mathrm{B}$ resulted in the highest degree of apoptosis in NHU cells, whereas in 253J cells, resistance was almost exclusively dependent on the p38 $8^{\mathrm{MAPK}}$ pathway (Figure 6a). Owing to the apparent association between susceptibility to TRAIL and loss of antiapoptotic proteins such as FLIP, we examined the possibility that changes in the expression of FLIP following combined treatment of urothelial cells with TRAIL and NF- $\kappa \mathrm{B} /$ p38 ${ }^{\mathrm{MAPK}}$ inhibitors could explain the differential apoptotic responses observed. Neither inhibitor had any effect on baseline expression of FLIP, IAP-2 and XIAP. Treatment with TRAIL in the presence of either inhibitor did not induce any notable changes in XIAP expression in NHU cells, whereas inhibition of NF- $\kappa$ B induced downregulation of FLIP $P_{L}$, FLIPS and to a lesser extent FLIP $_{43}$ (Figure 6b). By contrast, in 253J cells, inhibition of $\mathrm{p} 38^{\mathrm{MAPK}}$ and NF- $\kappa \mathrm{B}$ led to decreases in FLIP $_{\mathrm{L}}$ and $\mathrm{FLIP}_{43}$ although the decreases were more pronounced following inhibition of $\mathrm{p} 38^{\mathrm{MAPK}}$ (Figure $6 \mathrm{~b}$ ). These observations are concordant with the differential effects of $\mathrm{NF}_{\kappa}-\mathrm{B}$ and p38 ${ }^{\mathrm{MAPK}}$ inhibition on apoptosis in NHU and $253 \mathrm{~J}$ cells, respectively (Figure 6a). Collectively, the findings from our inhibitor studies clearly demonstrate a close correlation between sensitization to TRAIL-induced apoptosis and reduction of FLIP and suggest that resistance in normal cells is mainly dependent on the NF- $\kappa \mathrm{B}$ pathway, whereas tumor cells rely more on the $\mathrm{p} 38^{\mathrm{MAPK}}$ pathway to escape death.

\section{Effect of FLIPL knockdown on TRAIL-induced apoptosis}

Protein synthesis blockade and inhibition of NF- $\kappa \mathrm{B}$ and p38 $8^{\mathrm{MAPK}}$ pathways indicated a correlation between loss of FLIP and sensitization to apoptosis. However, these inhibitors may effect changes in multiple targets capable of altering TRAIL responsiveness. Therefore, to determine whether FLIP specifically protects against TRAIL-induced apoptosis in resistant urothelial cells, we used siRNA technology to knockdown FLIP $\mathrm{L}_{\mathrm{L}}$ expression. We used two small interfering RNAs (siRNAs) previously shown to knockdown FLIP expression, ${ }^{26,34}$ as detailed in Materials and Methods. FLIPL siRNA F1 did not reduce FLIP $\mathrm{L}_{\mathrm{L}}$ protein expression (Figure 7a) and had no effect on TRAIL-mediated apoptosis (Figure 7b). However, FLIPL siRNA F2 resulted in marked reduction of FLIP $\mathrm{L}_{\mathrm{L}}$ protein levels in NHU and 253J cells (Figure 7a) and induced a 3-4-fold increase in TRAIL-induced apoptosis in 253J cells $(P<0.001)$. By contrast, despite the diminution of FLIP $\mathrm{P}_{\mathrm{L}}$ protein expression, NHU cells only underwent an approximately two-fold increase in apoptosis $(P<0.01)$ (Figure 7b). A combination of the two siRNAs gave no greater effect than the FLIP $\mathrm{P}_{\mathrm{L}}$ siRNA F2 alone, as expected. Thus, it appears that FLIPL provides a significant level of protection against TRAIL-induced apoptosis in malignant urothelial cells.

\section{Discussion}

Few reports have addressed the putative tumor-selectivity of TRAIL by comparing carcinoma cells directly with their normal epithelial homologues, ${ }^{11,35}$ and susceptibility to TRAILinduced apoptosis in malignant urothelial cells has received scant attention. ${ }^{16,17}$ Our study is the first to systematically examine the relationship between TRAIL receptor expression and apoptotic susceptibility, and to address mechanisms of resistance to TRAIL-induced apoptosis of UCC-derived cells in comparison with their normal urothelial cell counterparts.

Our findings demonstrate that normal urothelial cells, unlike normal fibroblasts, are only partially resistant to crosslinked TRAIL. Although the majority of UCC cells have lost resistance and undergo rapid and extensive death, a spectrum of responses exists in carcinoma cells, as some are refractory and others are partially resistant, as exemplified by HT1376 and 253J cells, respectively. Our findings also support the suggestion that sensitivity of normal epithelial cells is related to the degree of TRAIL crosslinking. ${ }^{11,12}$ However, the tumor-selective effect of TRAIL could be significantly enhanced by using a noncrosslinked preparation and extending exposure time.

The strength of the TRAIL signal, thought to be a function of the degree of ligand crosslinking, is likely to determine the speed and efficiency by which TRAIL ligation induces DISC

Figure 3 Receptor blocking and recovery of viable urothelial cells following treatment with His-TRAIL. (a) EJ cells were seeded in 96-well plates and preincubated for $1 \mathrm{~h}$ with $10 \mu \mathrm{g} / \mathrm{ml}$ each of TRAIL-R1- and TRAIL-R2-blocking antibodies used alone or in combination as indicated; irrelevant isotype-matched antibodies at equivalent concentrations (10 and $20 \mu \mathrm{g} / \mathrm{ml})$ served as controls. His-TRAlL $(100 \mathrm{ng} / \mathrm{ml})$ was added for $6 \mathrm{~h}$, after which media were replaced with media containing $\left[{ }^{3} \mathrm{H}\right]$ thymidine $(0.5 \mu \mathrm{Ci} / w e l l)$ for a final $6 \mathrm{~h}$. Cells were harvested onto glass-fibre filtermats and $\left[{ }^{3} \mathrm{H}\right]$ thymidine incorporation (expressed as counts per minute, cpm) was assessed by liquid scintillation spectrometry. Percentage growth inhibition was calculated as $(S-E)-100 / S$, where $S=$ c.p.m. in control cultures and $E=c . p . m$. in test cultures, after background subtraction. Open bars represent cells cultured in control medium, filled bars represent TRAlL-treated cells and are means of five replicate wells ( \pm S.D.). Results are representative of two independent experiments. (b) NHU and UCC cells were seeded in 96-well plates and cultured with His-TRAIL at the concentrations indicated for $36 \mathrm{~h}$ prior to culture in growth medium containing $\left[{ }^{3} \mathrm{H}\right]$ thymidine $\left(0.5 \mu \mathrm{Ci} /\right.$ well) for a final $12 \mathrm{~h}$. $\left[{ }^{3} \mathrm{H}\right]$ thymidine incorporation was assessed as in $(\mathbf{a})$. Bars show means of sextuplicate wells $\left( \pm\right.$ S.D.) and are representative of two experiments. ${ }^{*}$ and ${ }^{*}$ indicate $P<0.01$ and $P<0.001$, respectively, by ANOVA with Dunnett post-test correction. (c) EJ cells were seeded in six-well plates and treated with control medium or $1000 \mathrm{ng} / \mathrm{ml}$ His-TRAlL for $36 \mathrm{~h}$ in duplicate. Surviving live cells were harvested and assessed for TRAIL receptor expression by flow cytometry; negative controls comprised secondary antibody alone (filled histograms). A proportion of the surviving cells were retained and cultured in normal growth medium for a further 7 days, harvested and assessed for TRAIL receptor expression as above 

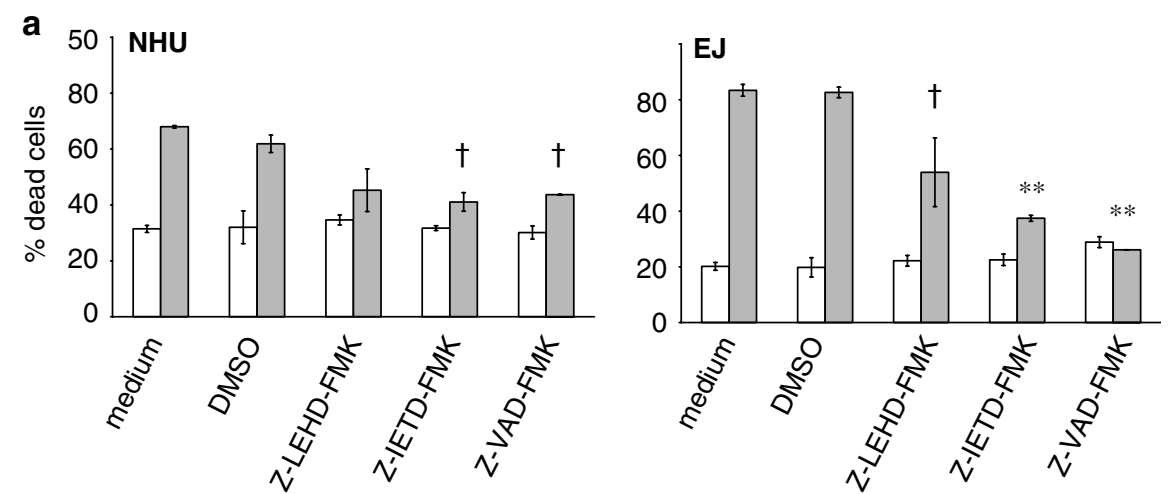

b
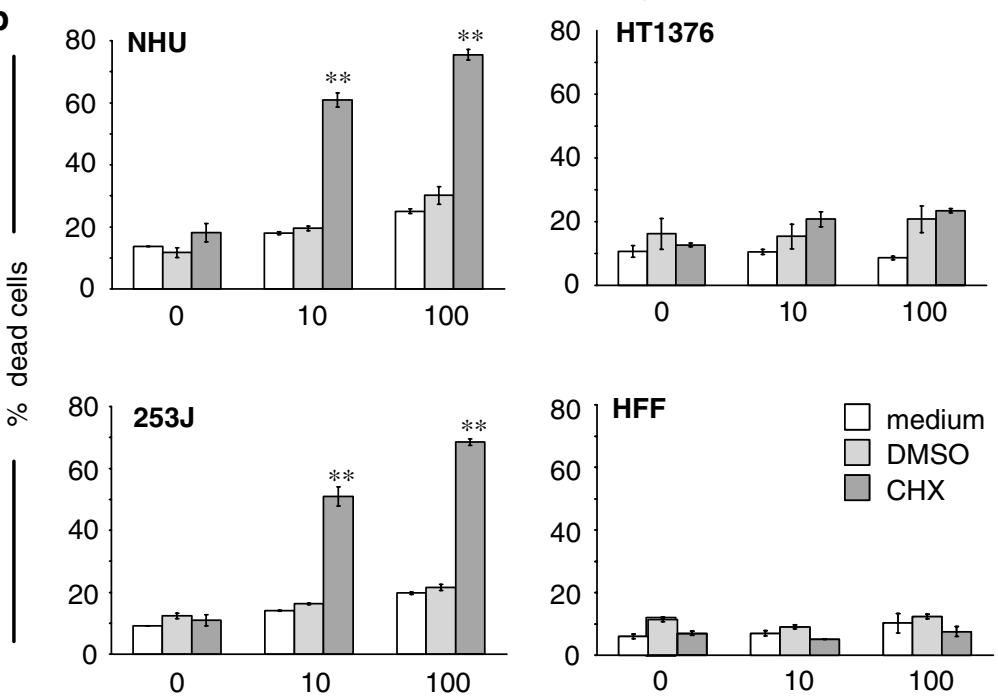

His-TRAIL $(\mathrm{ng} / \mathrm{ml})$

C

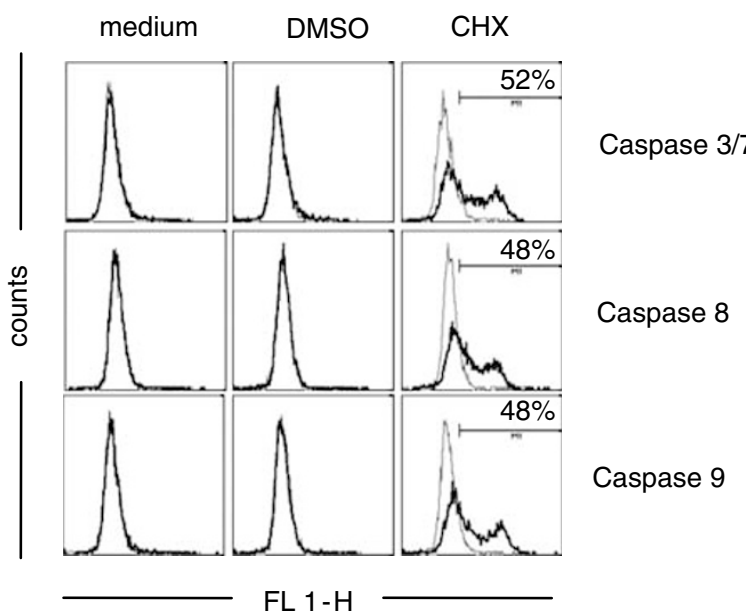

Figure 4 Effects of caspase and protein synthesis inhibition on TRAIL-induced apoptosis. (a) NHU and EJ cells were seeded in six-well plates and with preincubated medium, DMSO solvent control or $50 \mu \mathrm{M}$ of pan-caspase (z-VAD-FMK) or caspase-8 (z-IETD-FMK) inhibitor for $1 \mathrm{~h}$. Cells were cultured for a further $6 \mathrm{~h}$ with control medium (open bars) or His-TRAIL ( $100 \mathrm{ng} / \mathrm{ml}$, shaded bars) and apoptosis was assessed by Annexin V-FITC/PI flow cytometry. Bars represent means ( \pm S.D.) of duplicate wells and are representative of two experiments. (b) Partially resistant (NHU, 253J) and refractory (HT1376, HFF) cells were seeded in six-well plates and preincubated with medium alone (open bars), DMSO solvent control (pale bars) or cycloheximide (CHX; dark bars) at $0.1 \mu \mathrm{g} / \mathrm{ml}$ (NHU) or $1 \mu \mathrm{g} / \mathrm{ml}$ (HT1376, 253J and HFF) for $1 \mathrm{~h}$. Cells were then cultured for $6 \mathrm{~h}$ with His-TRAlL (10 and $100 \mathrm{ng} / \mathrm{ml}$ ) and apoptosis was assessed by Annexin V-FITC/PI flow cytometry. Bars represent means $( \pm$ S.D.) of duplicate wells and are pooled data from two independent experiments. (c) 253J cells were seeded in 24-well plates and precultured in medium, DMSO solvent control or $\mathrm{CHX}(1 \mu \mathrm{g} / \mathrm{ml})$ for $1 \mathrm{~h}$ as indicated, followed by culture in medium (gray histograms) or His-TRAlL ( $50 \mathrm{ng} / \mathrm{ml}$, black histograms). Activation of caspases-3/7, -8 and -9 was assessed after $3 \mathrm{~h}$ by flow cytometry (Materials and Methods). Representative data from two independent experiments are shown. Percentages of caspase-positive cells are as indicated. ${ }^{*}{ }^{*}$ and ${ }^{* *}$ indicate $P<0.05, P<0.01$ and $P<0.001$, respectively, by ANOVA with Tukey post-test correction 


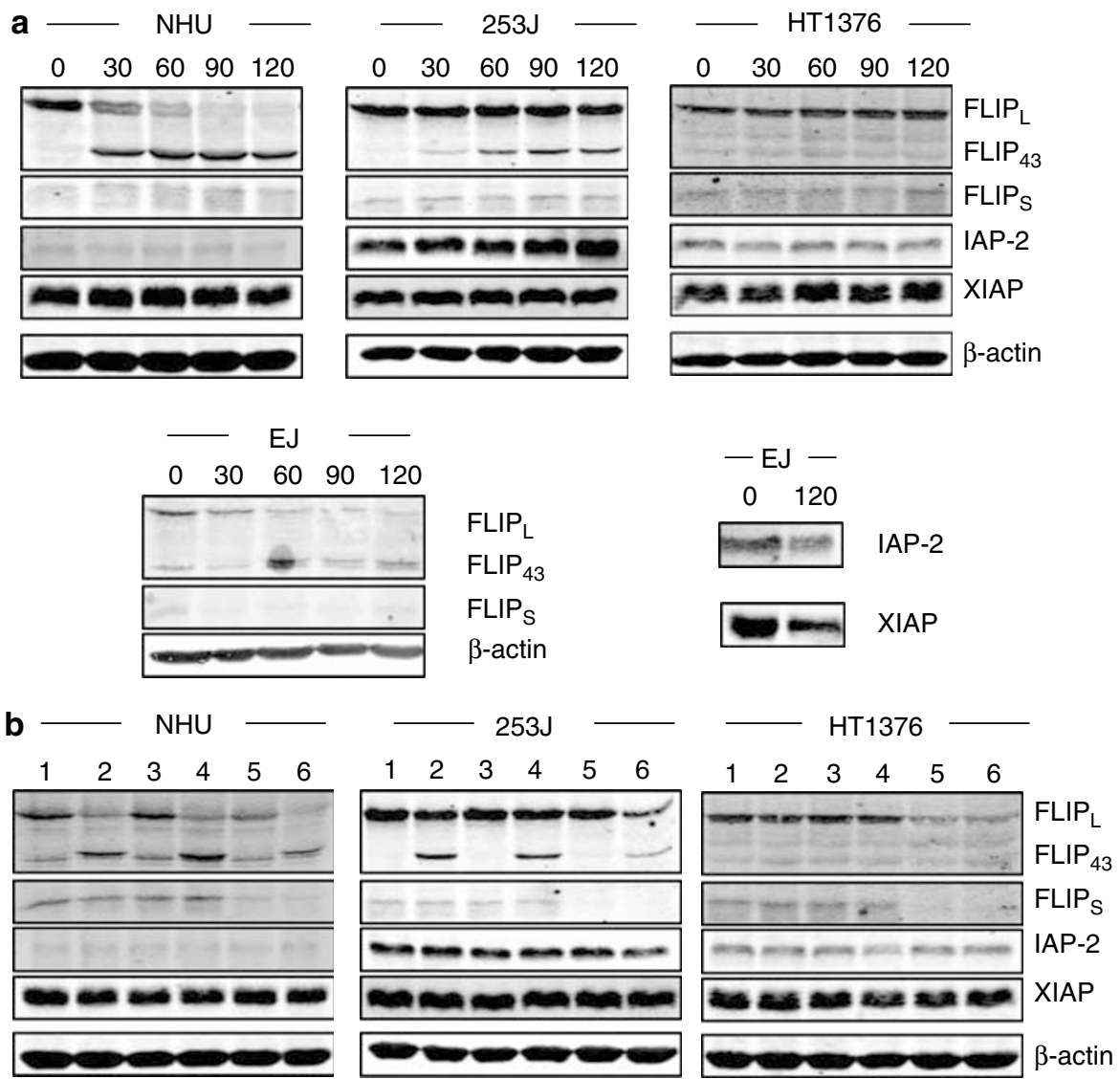

Figure 5 Expression and regulation of antiapoptotic proteins. Urothelial cells were seeded in $100 \mathrm{~mm}$ dishes and cultured overnight. Expression of antiapoptotic proteins was determined by SDS-PAGE and Western blotting following exposure to TRAIL alone (a) or after protein synthesis blockade by preincubation with cycloheximide (CHX) (b). (a) Cells were cultured with $50 \mathrm{ng} / \mathrm{ml} \mathrm{His-TRAlL}$ for $0,30,60,90$ and $120 \mathrm{~min}$, as indicated. Western blots were probed with antibodies against c-FLIP (NF-6), IAP-1, IAP-2 and XIAP. Equal protein loading was confirmed with anti- $\beta$-actin. Top panel shows partially resistant (NHU and 253J) and refractory (HT1376) cells, compared to TRAlL-sensitive EJ cells (bottom panel). Results are representative of three independent experiments. (b) NHU, 253J and HT1376 cells were preincubated in medium, DMSO solvent control or $\mathrm{CHX}(0.1 \mu \mathrm{g} / \mathrm{ml}$ for NHU and $1 \mu \mathrm{g} / \mathrm{ml}$ for HT1376 and $253 \mathrm{~J}$ cells) for $1 \mathrm{~h}$ and cultured with His-TRAlL ( $50 \mathrm{ng} / \mathrm{ml}$ ) for $90 \mathrm{~min}$. Whole-cell lysates were prepared and Western blotted as above. Results are representative of three independent experiments. Lanes represent: 1: Control; 2 : Control + TRAIL; 3: DMSO; 4: DMSO + TRAIL; 5: CHX and 6: CHX + TRAIL

formation and subsequent caspase activation. We found that prolonged exposure of malignant cells to noncrosslinked TRAIL eventually translated into a strong apoptotic signal resulting in extensive cell death. This dependency of a strong apoptotic effect on a high degree of ligand and consequently receptor crosslinking appears to be a common feature of the TNF superfamily. Our present findings mirror our previous observations in the CD40 system, whereby the degree of receptor crosslinking is fundamental to functional outcome. ${ }^{23}$

The apoptotic sensitivity of urothelial cells did not appear to be related to TRAIL receptor expression pattern, as DcR expression was essentially absent and some of the sensitive UCC-derived cells expressed a lower level of TRAIL death receptors than their relatively resistant normal cell counterparts. Our studies also demonstrate that the death signal in normal and transformed cells is transmitted principally by TRAIL-R1, consistent with observations in keratinocytes ${ }^{36}$ and in primary chronic lymphocytic leukemic cells, ${ }^{37}$ although TRAIL-R2 can transmit an equally potent death signal in urothelial cells if TRAIL-R1 is absent. Thus, in the urothelial system, a crosslinked His-TRAIL preparation can trigger apoptosis via either death receptor, suggesting that the functional receptor may be cell- and/or context-specific. Also worth noting is our finding that TRAIL receptor expression was relatively unaffected by archetypal regulatory cytokines, reminiscent of the situation described in thyroid epithelial cells. $^{38}$

Our observations reveal a novel mechanism of carcinoma cell escape from TRAIL-induced death, with the rapid emergence of a subset of TRAIL receptor-negative cells. Although evolution of colon carcinoma cells with partially deficient TRAIL-R1 transport to the cell surface has recently been described, this only occurred after long-term culture and clonal selection. ${ }^{39}$ By contrast, in our study, TRAIL-resistant cell populations arose rapidly, yet recovered receptor expression following removal of TRAIL. It is possible that high concentrations of TRAIL induce a negative-feedback loop which decreases receptor expression in surviving cells. It would be interesting to determine whether such a mechanism serves to protect epithelial cells from TRAIL toxicity under 


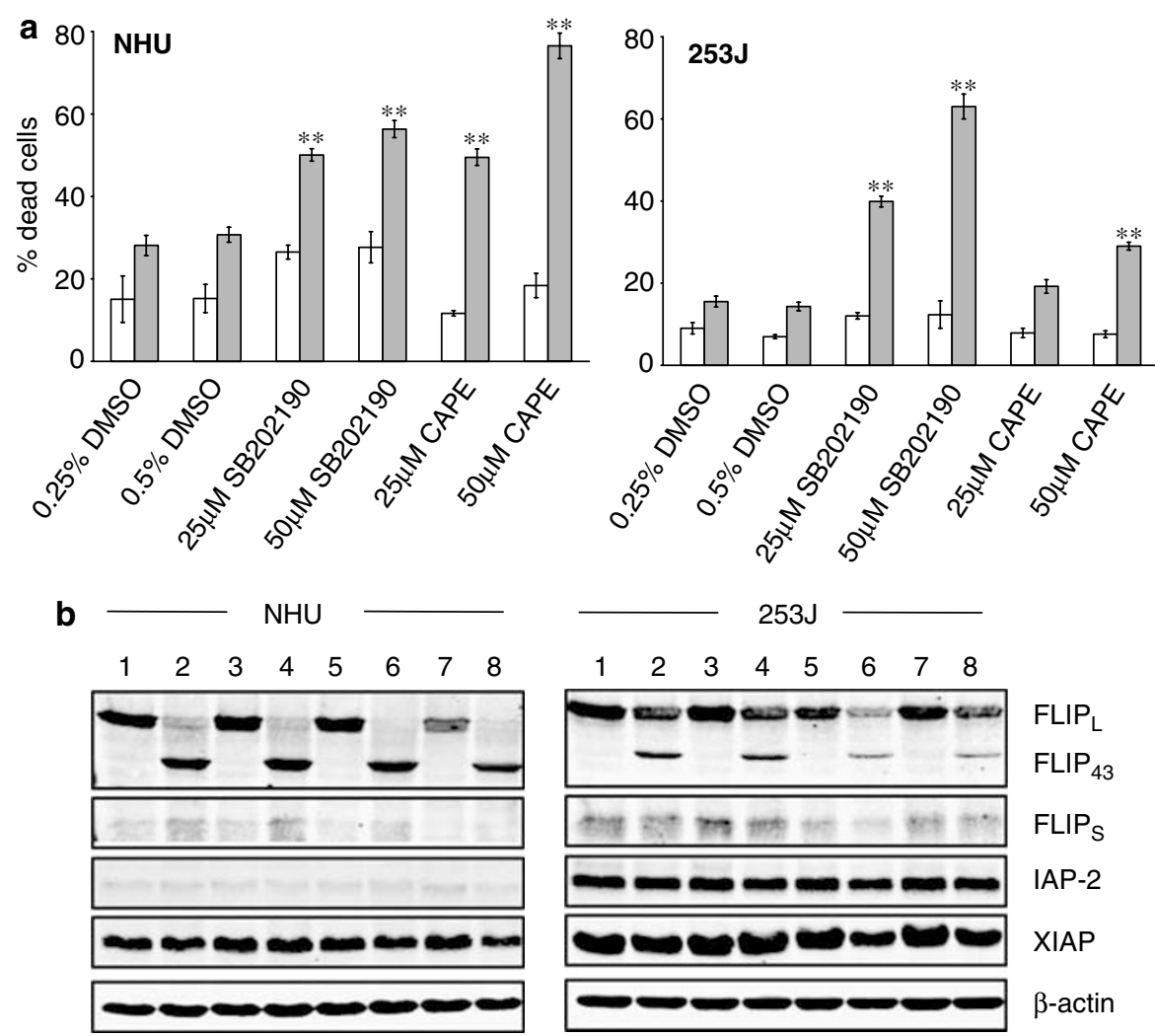

Figure 6 Effect of pharmacological inhibitors on expression of antiapoptotic proteins. (a) NHU and 253J cells were seeded in six-well plates and preincubated with either 25 or $50 \mu \mathrm{M}$ of p38 $8^{\mathrm{MAPK}}$ inhibitor (SB202190) or NF- $\kappa$ B inhibitor (CAPE), or equivalent DMSO solvent concentrations for $1 \mathrm{~h}$, prior to culture in control medium (open bars) or His-TRAIL ( $50 \mathrm{ng} / \mathrm{ml}$; pale bars) for $6 \mathrm{~h}$. Apoptosis was assessed by Annexin V-FITC/PI flow cytometry. Bars represent means ( \pm S.D.) of duplicate wells and are representative of two experiments. ${ }^{*}$ Indicates $P<0.001$ by ANOVA with Tukey post-test correction. (b) NHU and $253 \mathrm{~J}$ cells were seeded in $100 \mathrm{~mm}$ dishes and pretreated for $1 \mathrm{~h}$ with DMSO solvent control or $50 \mu \mathrm{M}$ SB202190 or $50 \mu \mathrm{M}$ CAPE prior to culture in control medium or His-TRAlL (50 ng/ml) for $90 \mathrm{~min}$. Whole-cell lysates were prepared and Western blotted for antiapoptotic proteins as above. Results are representative of at least three independent experiments. Lanes represent: 1 : medium alone; 2: medium + TRAIL; 3: DMSO alone; 4: DMSO + TRAIL; 5: SB202190 alone; 6: SB202190 + TRAIL; 7: CAPE alone and 8: CAPE + TRAIL

a
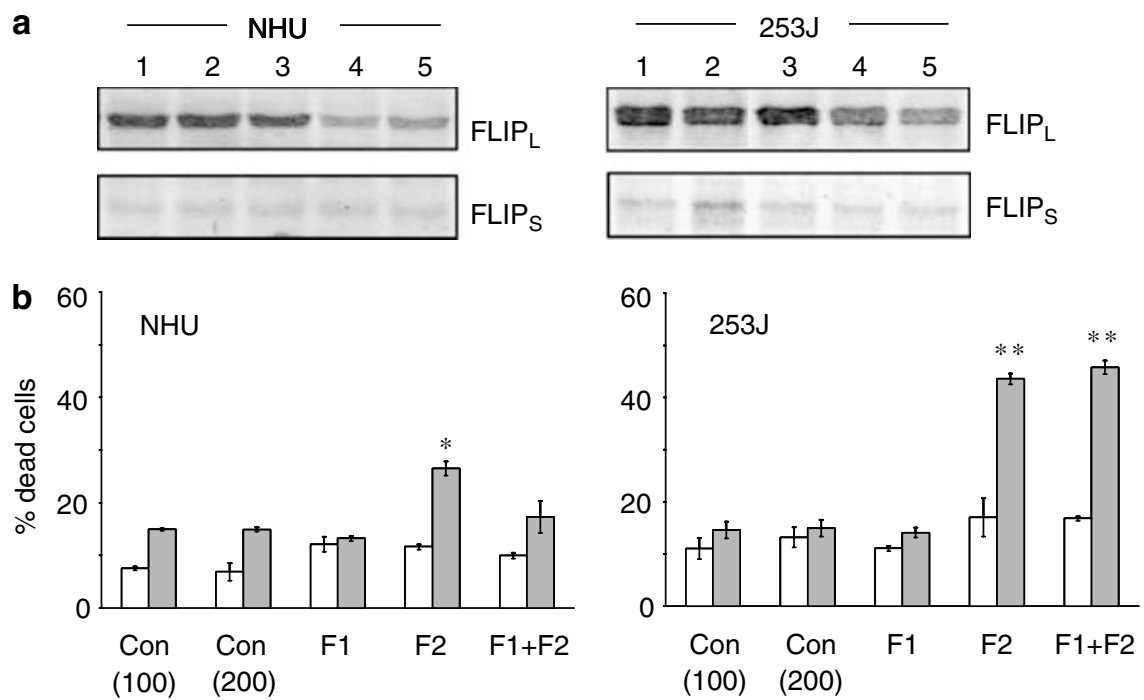

Figure 7 Effect of FLIP knockdown on susceptibility to TRAIL-induced apoptosis. (a) Urothelial cells were seeded in $100 \mathrm{~mm}$ dishes and transfected with $100 \mathrm{nM}$ $F L I P_{L}$ siRNA F1 or FLIP $P_{L}$ siRNA F2 alone or in combination. Control plates containing equivalent concentrations of control siRNA (Con) were also included. Cell lysates were prepared and Western blotted. Membranes were probed with monoclonal antibody against FLIP (NF-6), and $\beta$-actin was used to confirm equal track loading. Lanes represent: 1: Con 100 nM; 2: Con 200 nM; 3: F1 100 nM; 4: F2 100 nM; 5: F1 and F2 (100 nm each). (b) Urothelial cells were seeded in six-well plates and transfected with $100 \mathrm{nM}$ of $\mathrm{F} 1$ or $\mathrm{F} 2$ siRNAs alone or in combination. Control plates containing equivalent concentrations of Con siRNA were included. Cells were treated with normal growth medium (open bars) or $50 \mathrm{ng} / \mathrm{ml}$ His-TRAIL (shaded bars) and apoptosis was assessed by AnnexinV-FITC/PI flow cytometry. Bars represent means ( \pm S.D.) of duplicate wells and are representative of at least three independent experiments. ${ }^{*} P<0.01$ and ${ }^{* *} P<0.001$ by ANOVA with Tukey post-test correction 
physiological circumstances, and ultimately allows tumor cells to evade TRAIL-mediated elimination.

An examination of the apoptotic pathways showed that TRAIL-mediated death in normal and malignant urothelial cells occurred via caspase- 8 and -9 , in agreement with previous studies demonstrating that TRAIL can trigger both the extrinsic and intrinsic death pathways. ${ }^{40}$ Therefore, although $\mathrm{NHU}$ cells have a higher threshold and require a more potent apoptotic signal than many of their malignant counterparts, once triggered, a common death effector mechanism is engaged in both normal and tumor cells, even when apoptosis requires inhibition of protein synthesis.

The several-fold increase in apoptotic sensitivity following protein synthesis blockade in NHU and 253 J cells implies that partial resistance is mediated by intracellular anti-apoptotic proteins, ${ }^{41}$ rather than by decoy receptors. These findings are consistent with those reported in keratinocytes. ${ }^{35}$ Intracellular factor(s), such as FLIP and IAPs, have previously been implicated in TRAIL resistance in some bladder ${ }^{16}$ and hepatocellular carcinoma cells. ${ }^{42}$ Furthermore, a previous study has correlated levels of FLIP mRNA with TRAIL resistance in malignant urothelial cells. ${ }^{43}$ However, our study is the first to correlate apoptotic susceptibility in malignant and normal urothelial cells with expression of FLIP at the protein level. Highly sensitive cells underwent rapid loss of FLIP whereas TRAIL-refractory cells showed no change in FLIP expression. In partially resistant cells, FLIP underwent processing to the $43 \mathrm{kDa}$ fragment $\left(\mathrm{FLIP}_{43}\right)$. $\mathrm{FLIP}_{43}$ is thought to remain bound at the DISC, blocking apoptosis ${ }^{28}$ and therefore generation of this fragment would explain the partial resistance of these cells. Following blockade of protein synthesis, partially resistant cells showed a decrease in FLIP $_{\mathrm{L}}$, FLIP $_{\mathrm{S}}$ and FLIP $_{43}$ which coincided with activation of caspase-8, -9 and -3 and increased levels of apoptosis. By contrast, neither IAP-2 nor XIAP were affected.

In agreement with recent observations, ${ }^{44}$ our studies demonstrate that FLIP $_{\mathrm{L}}$ is a key determinant in mediating TRAIL resistance in malignant urothelial cells. Sensitization to TRAIL-induced apoptosis after pretreatment with CHX, CAPE

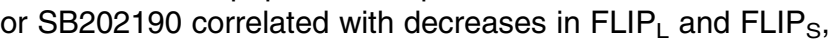
and siRNA knockdown experiments showed a marked increase in apoptotic susceptibility that correlated with the degree of loss of FLIP protein expression. FLIP $P_{L}$-mediated protection from TRAIL toxicity, however, appears to be more a feature of malignant cells as downregulation of FLIP $\mathrm{L}_{\mathrm{L}}$ did not increase susceptibility to TRAIL-mediated apoptosis in normal urothelial cells to the same extent. At present, the contribution, if any, of FLIPS in mediating TRAIL resistance in urothelial cells is unknown and it is possible that FLIP $\mathrm{L}_{\mathrm{L}}$ and FLIPS isoforms act in concert. It would be interesting to determine the apoptotic response of TRAIL-resistant cells following knockdown of both FLIP $\mathrm{L}_{\mathrm{L}}$ and FLIP $\mathrm{S}$ isoforms.

Recent studies have implicated $\mathrm{p} 38^{\mathrm{MAPK}}$ and $\mathrm{NF}-\kappa \mathrm{B}$ signaling pathways as key mediators of TRAIL resistance. ${ }^{45,46}$ We report that TRAIL-induced apoptosis was potentiated by inhibition of NF- $\kappa$ B in normal cells and p38 $8^{\mathrm{MAPK}}$ blockade in malignant cells, respectively, and in both cases apoptotic susceptibility directly correlated with the degree of loss of FLIP and FLIP $_{43}$. The precise role of $N F-\kappa B$ and p38 ${ }^{\mathrm{MAPK}}$ pathways in resistance to TRAIL-induced apoptosis remains unclear. It has been reported that $\mathrm{p} 38^{\mathrm{MAPK}}$ is required for NF- $\kappa$ B-driven gene transcription in response to TNF $\alpha^{47}$ and can critically affect NF- $\kappa$ B activation. ${ }^{48,49}$ However, since sensitization of $\mathrm{NHU}$ cells occurred mainly following inhibition of $\mathrm{NF}-\kappa \mathrm{B}$ and the $\mathrm{p} 38^{\mathrm{MAPK}}$ inhibitor preferentially increased tumor cell susceptibility to TRAIL, it is unlikely that p38 ${ }^{\text {MAPK }}$ functions solely along the $\mathrm{NF}-\kappa \mathrm{B}$ signaling axis in either normal or malignant cells.

Although clearly important, involvement of antiapoptotic factors cannot be the only mechanism of resistance to TRAILmediated death, as both normal fibroblasts and carcinomaderived HT1376 cells remained refractory even after inhibition of protein synthesis, despite downregulation of FLIP isoforms. The resistance of HT1376 cells may reflect a loss of expression of a vital component(s) of the TRAIL pathway, such as FADD. However, what confers complete resistance to TRAIL in normal cells of non-epithelial origin, such as fibroblasts, is intriguing. Work in our laboratory has shown that both human and murine fibroblasts are completely refractory to TRAIL and FasL even at extremely high concentrations of agonist, yet become massively susceptible if exposed to membrane-presented ligand or if these death ligands are expressed intracellularly (unpublished observations), in agreement with previously published reports. ${ }^{50,51}$ Resistance of mesenchymal cells to strong apoptotic signals, although physiologically vital, constitutes an unexplored field that could provide insights into mechanisms of tumor cell evasion.

In conclusion, we have demonstrated a differential sensitivity to TRAIL-induced apoptosis in normal versus malignant human urothelial cells, independent of tumor grade and TRAIL receptor expression. It appears that, despite some vulnerability of normal cells to crosslinked TRAIL, it is possible to achieve a high degree of tumor-specific apoptosis in malignant urothelial cells. We also show that FLIP $\mathrm{L}_{\mathrm{L}}$ is a major determinant of apoptotic susceptibility in malignant urothelial cells and that $\mathrm{p} 38^{\mathrm{MAPK}}$ inhibition sensitizes resistant tumor cells to apoptosis by downregulating FLIP and its derivatives. Furthermore, the differential usage of NF- $\kappa \mathrm{B}$ versus $\mathrm{p} 38^{\mathrm{MAPK}}$ pathways by normal versus tumor cells to ameliorate the proapoptotic effects of TRAIL and the selective protection of malignant urothelial cells via FLIP $P_{L}$ suggests possible avenues for therapeutic intervention to promote the differential killing of malignant cells.

\section{Materials and Methods}

\section{Cell culture}

$\mathrm{NHU}$ cell lines were established from urothelial tissues obtained during surgery from patients with no history of urothelial cancer, as described, ${ }^{18,19}$ following Local Research Ethics Committee approval and patient consent. NHU cell lines were cultured in complete keratinocyte serum-free medium (KSFM) (Gibco-BRL, Paisley, UK) containing $30 \mathrm{ng} / \mathrm{ml}$ cholera toxin (Sigma Chemical Co., Poole, UK) ${ }^{18,19}$ and used between passages 2-6.

Six established human UCC-derived cell lines were studied, comprising RT4, HT1376, RT112, VM-CUB-3, 253J and EJ, to encompass phenotypes ranging from well differentiated to highly anaplastic. ${ }^{22}$ Normal human foreskin fibroblasts (HFF) were from Cancer Research UK Cell 
Services (Clare Hall Laboratories, UK) and the TRAIL-sensitive Jurkat J6 cell line was from the European Collection of Animal Cell Cultures (Porton Down, UK). Established cell lines were maintained in a 1:1 (v/v) mixture of RPMI 1640 and DMEM (Sigma Chemical Co) with 5 or $10 \%$ fetal bovine serum (TCS Cellworks, Bucks, UK).

\section{Cell death and proliferation assays}

Apoptosis was determined by phase-contrast microscopy and quantified by flow cytometry by criteria of Annexin V-FITC/PI (BD Pharmingen, Oxford, UK) labeling as described, ${ }^{23}$ or by expression of activated Caspase-3/7, -8 and -9 , using FAM FLICA Caspase Detection Kits according to the manufacturer's instructions (Serotec, Oxford, UK). Cells were analyzed on a FACSCalibur ${ }^{\mathrm{TM}}$ instrument using CellQuest $\mathrm{Pro}^{\mathrm{TM}}$ software (BD, Oxford, UK), acquiring 5000 events per sample.

Thymidine incorporation assays ${ }^{23}$ were used to estimate the recovery of viable, proliferative cells following exposure to TRAIL. Cells were plated in replicate wells of 96-well plates and allowed to attach prior to exposure to TRAIL, with addition of $\left[{ }^{3} \mathrm{H}\right.$ ]thymidine $(0.5 \mu \mathrm{Ci} /$ well $)$ for the final $6 \mathrm{~h}$. Cells were harvested onto glass-fiber filter mats and precursor incorporation was assessed by liquid scintillation spectrometry.

\section{TRAIL receptor expression and cytokine modulation}

Expression of TRAIL receptors was determined by flow cytometry ${ }^{23}$ using antibodies to TRAIL-R1 (\#HS101), TRAIL-R2 (\#HS201), TRAIL-R3 (\#HS301) and TRAIL-R4 (\#HS402) (Alexis Corp, Nottinghamshire, UK) and a secondary phycoerythrin (PE)-conjugated goat anti-mouse Ig (F[ab]'2 fragment) antibody (Southern Biotechnology Associates from Cambridge Biosciences, Cambridge, UK).

To determine the effects of pro- and anti-inflammatory cytokines on TRAIL receptor expression, urothelial cells were treated with TNF $\alpha$, interferon (IFN) $\gamma(0-1000 \mathrm{U} / \mathrm{ml})$, transforming growth factor (TGF) $\beta$ or interleukin (IL)-4 (0-100 U/ml) in duplicate. Cells were harvested after $72 \mathrm{~h}$ and receptor expression was examined by flow cytometry. Biological activity of the cytokines was confirmed using established positive controls.

\section{TRAIL receptor ligation and functional blocking studies}

Cells were treated with various concentrations of His-TRAIL or FLAGTRAIL (Alexis Corp) for time periods as indicated. FLAG-TRAIL was used alone or in the presence of crosslinker (anti-FLAG antibody, Alexis Corp) at $2 \mu \mathrm{g} / \mathrm{ml}$. Growth medium-alone controls were included in all assays. For some experiments, cells were pretreated with $\mathrm{CHX}$ (Sigma Chemical Co.) for $1 \mathrm{~h}$ at pretitered concentrations of $1 \mu \mathrm{g} / \mathrm{ml}$ for UCC-derived cell lines and $0.1 \mu \mathrm{g} / \mathrm{ml}$ for NHU cells. ${ }^{23}$ For antibody blocking experiments, cells were preincubated with $10 \mu \mathrm{g} / \mathrm{ml}$ of anti-TRAIL (\#2E5), anti-TRAIL-R1 (\#HS101) or anti-TRAIL-R2 (\#HS201) (Alexis Corp) for $1 \mathrm{~h}$ prior to addition of His-TRAIL to final concentrations of 10 and $100 \mathrm{ng} / \mathrm{ml}$. An irrelevant IgG1 antibody served as a negative control. For caspase inhibition experiments, cells were preincubated with inhibitors of caspase-8 (z-IETDFMK), caspase-9 (z-LEHD-FMK) or pan-Caspase (z-VAD-FMK; Calbiochem, Notts, UK) at $50 \mu \mathrm{M}$ for $1 \mathrm{~h}$ prior to addition of TRAIL. Apoptosis was assessed by Annexin V/PI after $6 \mathrm{~h}$. Caspase inhibitors were reconstituted in dimethyl sulfoxide (DMSO) and solvent-only controls were included in all experiments.

\section{Western blot analysis}

$1.5 \times 10^{6}$ urothelial cells were seeded in $100 \mathrm{~mm}$ dishes (Falcon), allowed to adhere overnight, and treated with $50 \mathrm{ng} / \mathrm{ml}$ His-TRAIL for up to $2 \mathrm{~h}$, or preincubated with $\mathrm{CHX}$ or $50 \mu \mathrm{M}$ of pharmacological inhibitors (SB202190 and Caffeic Acid Phenethyl Ester (CAPE), Alexis Corp.) for $1 \mathrm{~h}$ prior to addition of $50 \mathrm{ng} / \mathrm{ml}$ His-TRAIL for a further $90 \mathrm{~min}$. Western blots were carried out as described. ${ }^{23}$ Membranes were probed with antibodies against cFLIP (NF-6) (Alexis Corp), XIAP (Transduction Laboratories), IAP-1 and IAP-2 (BD Pharmingen). The specificity of the IAP-2 antibody (clone F30-2285) was verified by immunblotting using COS-7 cells transfected with human IAP-1 and IAP-2 expression constructs (Supplementary Figure 3). In total, $20 \mu \mathrm{g}$ protein was loaded per track and antibody binding was detected using an Odyssey system (LI-COR Biosciences UK, Cambridge, UK). Equal track loading was confirmed using monoclonal antibody against $\beta$-actin (Sigma).

\section{RNA interference (RNAi) studies}

siRNAs were purchased from Ambion and reconstituted to a concentration of $40 \mu \mathrm{M}$ according to the manufacturer's instructions. Two previously published siRNA oligonucleotides against $F_{L} P_{L}$ were used as well as an irrelevant (green fluorescent protein-specific) control siRNA. The sequences were

FLIPL siRNA F1: 5'-AACUGCUCUACAGAGUGAGGC- $3^{\prime},{ }^{26}$

FLIP $_{L}$ SIRNA F2: 5'-AACAUCCACAGAAUAGACCUG- $3^{\prime},{ }^{34}$ and

Control (Con) 5'-AAGGACGACGGAAACUACAAG-3'.

Urothelial cells were transfected with either $100 \mathrm{nM}$ (this concentration was optimized following initial titration experiments) of F1 or F2 siRNAs alone or in combination. Control transfections using equivalent concentrations of Con siRNA were included in each experiment. Transfections were carried out in serum-free media using OligofectAMINE (Invitrogen) for 6-7h. Media were then replenished with serum and supplements and cells were cultured in the continued presence of siRNA overnight. Cells were then treated with either normal growth medium or $50 \mathrm{ng} / \mathrm{ml}$ His-TRAIL and apoptosis was assessed $6 \mathrm{~h}$ later by AnnexinVFITC/PI assay. In parallel, cell lysates were prepared from urothelial cells treated as above and separated by SDS-PAGE as described previously. ${ }^{23}$ Membranes were probed for FLIP $P_{L}$ and equal track loading was confirmed using a monoclonal antibody against $\beta$-actin.

\section{NF- $\kappa$ B activity assay}

Activation of NF- $\kappa \mathrm{B}$ in control versus CAPE-treated urothelial cells was determined using the TransAM ${ }^{\mathrm{TM}}$ NF- $\kappa \mathrm{B}$ Family Kit (Active Motif, Rixensart, Belgium) according to the manufacturer's instructions. Briefly, urothelial cells were seeded in $100 \mathrm{~mm}$ dishes, allowed to adhere overnight, and cultured in normal growth media or $50 \mu \mathrm{M}$ CAPE for $1 \mathrm{~h}$ prior to the addition of $50 \mathrm{ng} / \mathrm{ml} \mathrm{His-TRAIL}$ for a further $60 \mathrm{~min}$. Nuclear fractions were prepared using the Active Motif Nuclear Extract Kit according to the manufacturer's instructions. In total, $10 \mu \mathrm{g}$ of extract was applied to a 96-well plate containing an immobilized NF- $\kappa$ B consensus site (5'-GGGACTTTCC-3'). Primary antibodies directed against the p50 and p65 subunits of NF- $\kappa$ B were added followed by an HRP-conjugated secondary antibody. Activity was determined by absorbance at $450 \mathrm{~nm}$. The specificity of the assay was confirmed by competition experiments using NF- $\kappa$ B wild-type or mutated oligonucleotide.

\section{Statistical analysis}

Means and standard deviations were used as descriptive statistics. For determination of statistical significance, Instat GraphPAD (San Diego, CA, 
USA) was used for one-way analysis of variance (ANOVA) with Dunnett or Tukey post-test corrections.

\section{Acknowledgements}

We thank Hideo Yagita (Department of Immunology, Juntendo University School of Medicine, Tokyo, Japan) for providing reagents and Robert Korneluk and Stephanie Plenchette (Children's Hospital of Eastern Ontario Research Institute and Department of Biochemistry, Microbiology, and Immunology, University of Ottawa, Canada) for their gifts of human cIAP constructs. We also thank Miss Lisa Clements for technical assistance with COS-7 cell transfections. This work was supported by Cancer Research UK.

\section{References}

1. Ashkenazi A (2002) Targeting death and decoy receptors of the tumournecrosis factor superfamily. Nat. Rev. Cancer 2: 420-430

2. Sheridan JP, Marsters SA, Pitti RM, Gurney A, Skubatch M, Baldwin D, Ramakrishnan L, Gray CL, Baker K, Wood WI, Goddard AD, Godowski P and Ashkenazi A (1997) Control of TRAIL-induced apoptosis by a family of signaling and decoy receptors. Science 277: 818-821

3. Kischkel FC, Hellbardt S, Behrmann I, Germer M, Pawlita M, Krammer PH and Peter ME (1995) Cytotoxicity-dependent APO-1 (Fas/CD95)-associated proteins form a death-inducing signaling complex (DISC) with the receptor. EMBO J. 14: 5579-5588

4. Kischkel FC, Lawrence DA, Chuntharapai A, Schow P, Kim KJ and Ashkenazi A (2000) Apo2L/TRAIL-dependent recruitment of endogenous FADD and caspase-8 to death receptors 4 and 5 . Immunity 12: 611-620

5. Almasan A and Ashkenazi A (2003) Apo2L/TRAIL: apoptosis signaling biology, and potential for cancer therapy. Cytokine Growth Factor Rev. 14: 337-348

6. Wang S and EI Deiry WS (2003) TRAIL and apoptosis induction by TNF-family death receptors. Oncogene 22: 8628-8633

7. Walczak H, Miller RE, Ariail K, Gliniak B, Griffith TS, Kubin M, Chin W, Jones J, Woodward A, Le T, Smith C, Smolak P, Goodwin RG, Rauch CT, Schuh JC and Lynch DH (1999) Tumoricidal activity of tumor necrosis factor-related apoptosis-inducing ligand in vivo. Nat. Med. 5: 157-163

8. Tillman DM, Izeradjene K, Szucs KS, Douglas L and Houghton JA (2003) Rottlerin sensitizes colon carcinoma cells to tumor necrosis factor-related apoptosis-inducing ligand-induced apoptosis via uncoupling of the mitochondria independent of protein kinase C. Cancer Res. 63: 5118-5125

9. Singh TR, Shankar S, Chen X, Asim M and Srivastava RK (2003) Synergistic interactions of chemotherapeutic drugs and tumor necrosis factor-related apoptosis-inducing ligand/Apo-2 ligand on apoptosis and on regression of breast carcinoma in vivo. Cancer Res. 63: 5390-5400

10. Jo M, Kim TH, Seol DW, Esplen JE, Dorko K, Billiar TR and Strom SC (2000) Apoptosis induced in normal human hepatocytes by tumor necrosis factorrelated apoptosis-inducing ligand. Nat. Med. 6: 564-567

11. Nesterov A, Ivashchenko $Y$ and Kraft AS (2002) Tumor necrosis factor-related apoptosis-inducing ligand (TRAIL) triggers apoptosis in normal prostate epithelial cells. Oncogene 21: 1135-1140

12. Qin J, Chaturvedi V, Bonish B and Nickoloff BJ (2001) Avoiding premature apoptosis of normal epidermal cells. Nat. Med. 7: 385-386

13. Schneider $P$ (2000) Production of recombinant TRAIL and TRAIL receptor: Fc chimeric proteins. Methods Enzymol. 322: 325-345

14. Ashkenazi A and Dixit VM (1999) Apoptosis control by death and decoy receptors. Curr. Opin. Cell. Biol. 11: 255-260

15. Muhlenbeck F, Schneider P, Bodmer JL, Schwenzer R, Hauser A, Schubert G, Scheurich P, Moosmayer D, Tschopp J and Wajant H (2000) The tumo necrosis factor-related apoptosis-inducing ligand receptors TRAIL-R1 and TRAIL-R2 have distinct cross-linking requirements for initiation of apoptosis and are non-redundant in JNK activation. J. Biol. Chem. 275: 32208-32213

16. Jonsson G, Paulie S and Grandien A (2003) clAP-2 block apoptotic events in bladder cancer cells. Anticancer Res. 23: 3311-3316
17. Mizutani Y, Nakao M, Ogawa O, Yoshida O, Bonavida B and Miki T (2001) Enhanced sensitivity of bladder cancer cells to tumor necrosis factor related apoptosis inducing ligand mediated apoptosis by cisplatin and carboplatin. J. Urol. 165: 263-270

18. Southgate J, Hutton KA, Thomas DF and Trejdosiewicz LK (1994) Normal human urothelial cells in vitro: proliferation and induction of stratification. Lab. Invest. 71: 583-594

19. Southgate J, Masters JR and Trejdosiewicz LK (2002) Culture of human urothelium. In Culture of Epithelial Cells Freshney RI and Freshney RG (eds) (New York, NY: J. Wiley and Sons, Inc.) pp. 381-400

20. Varley CL, Stahlschmidt J, Lee WC, Holder J, Diggle C, Selby PJ, Trejdosiewicz LK and Southgate J (2004) Role of PPARgamma and EGFR signalling in the urothelial terminal differentiation programme. J. Cell Sci. 117: 2029-2036

21. Booth C, Harnden P, Trejdosiewicz LK, Scriven S, Selby PJ and Southgate J (1997) Stromal and vascular invasion in an human in vitro bladder cancer model. Lab. Invest. 76: 843-857

22. Masters JR, Hepburn PJ, Walker L, Highman WJ, Trejdosiewicz LK, Povey S, Parkar M, Hill BT, Riddle PR and Franks LM (1986) Tissue culture model of transitional cell carcinoma: characterization of twenty-two human urothelial cell lines. Cancer Res. 46: 3630-3636

23. Bugajska U, Georgopoulos NT, Southgate J, Johnson PW, Graber P, Gordon J, Selby PJ and Trejdosiewicz LK (2002) The effects of malignant transformation on susceptibility of human urothelial cells to CD40-mediated apoptosis. J. Natl. Cancer Inst. 94: 1381-1395

24. Zhang XD, Nguyen T, Thomas WD, Sanders JE and Hersey P (2000) Mechanisms of resistance of normal cells to TRAIL induced apoptosis vary between different cell types. FEBS Lett. 482: 193-199

25. Wajant H, Moosmayer D, Wuest T, Bartke T, Gerlach E, Schonherr U, Peters $\mathrm{N}$, Scheurich $\mathrm{P}$ and Pfizenmaier K (2001) Differential activation of TRAIL-R1 and -2 by soluble and membrane TRAIL allows selective surface antigendirected activation of TRAIL-R2 by a soluble TRAIL derivative. Oncogene 20: 4101-4106

26. Chawla-Sarkar M, Bae SI, Reu FJ, Jacobs BS, Lindner DJ and Borden EC (2004) Downregulation of Bcl-2, FLIP or IAPs (XIAP and survivin) by siRNAs sensitizes resistant melanoma cells to Apo2L/TRAIL-induced apoptosis. Cell Death Differ. 11: 915-923

27. Zhang X, Jin TG, Yang H, DeWolf WC, Khosravi-Far R and Olumi AF (2004) Persistent $c-F L I P(L)$ expression is necessary and sufficient to maintain resistance to tumor necrosis factor-related apoptosis-inducing ligand-mediated apoptosis in prostate cancer. Cancer Res. 64: 7086-7091

28. Krueger A, Schmitz I, Baumann S, Krammer PH and Kirchhoff S (2001) Cellular FLICE-inhibitory protein splice variants inhibit different steps of caspase-8 activation at the CD95 death-inducing signaling complex. J. Biol. Chem. 276: 20633-20640

29. Lee MW, Park SC, Yang YG, Yim SO, Chae HS, Bach JH, Lee HJ, Kim KY, Lee WB and Kim SS (2002) The involvement of reactive oxygen species (ROS) and p38 ${ }^{\text {MAPK }}$ mitogen-activated protein (MAP) kinase in TRAIL/Apo2L-induced apoptosis. FEBS Lett. 512: 313-318

30. Ehrhardt H, Fulda S, Schmid I, Hiscott J, Debatin KM and Jeremias I (2003) TRAIL induced survival and proliferation in cancer cells resistant towards TRAIL-induced apoptosis mediated by NF-kappaB. Oncogene 22: 3842-3852

31. Natarajan K, Singh S, Burke Jr TR, Grunberger D and Aggarwal BB (1996) Caffeic acid phenethyl ester is a potent and specific inhibitor of activation of nuclear transcription factor NF-kappa B. Proc. Natl. Acad. Sci. USA 93: 9090-9095

32. Young PR, McLaughlin MM, Kumar S, Kassis S, Doyle ML, McNulty D, Gallagher TF, Fisher S, McDonnell PC, Carr SA, Huddleston MJ, Seibel G, Porter TG, Livi GP, Adams JL and Lee JC (1997) Pyridinyl imidazole inhibitors of $\mathrm{p} 38^{\text {MAPK }}$ mitogen-activated protein kinase bind in the ATP site. J. Biol. Chem. 272: 12116-12121

33. Williamson AJ, Dibling BC, Boyne JR, Selby P and Burchill SA (2004) Basic fibroblast growth factor-induced cell death is effected through sustained activation of p38MAPK and up-regulation of the death receptor p75NTR. J. Biol. Chem. 279: 47912-47928

34. Siegmund D, Hadwiger $P$, Pfizenmaier K, Vornlocher HP and Wajant $H$ (2002) Selective inhibition of FLICE-like inhibitory protein expression with small interfering RNA oligonucleotides is sufficient to sensitize tumor cells for TRAILinduced apoptosis. Mol. Med. 8: 725-732 
35. Leverkus M, Neumann M, Mengling T, Rauch CT, Brocker EB, Krammer PH and Walczak H (2000) Regulation of tumor necrosis factor-related apoptosisinducing ligand sensitivity in primary and transformed human keratinocytes. Cancer Res. 60: 553-559

36. Leverkus M, Sprick MR, Wachter T, Denk A, Brocker EB, Walczak H and Neumann M (2003) TRAlL-induced apoptosis and gene induction in HaCaT keratinocytes: differential contribution of TRAIL receptors 1 and 2. J. Invest. Dermatol. 121: 149-155

37. MacFarlane M, Inoue S, Kohlhaas SL, Majid A, Harper N, Kennedy DB, Dyer MJ and Cohen GM (2005) Chronic lymphocytic leukemic cells exhibit apoptotic signaling via TRAIL-R1. Cell Death Differ. 12: 773-782

38. Bretz JD, Mezosi E, Giordano TJ, Gauger PG, Thompson NW and Baker JR (2002) Inflammatory cytokine regulation of TRAIL-mediated apoptosis in thyroid epithelial cells. Cell Death Differ. 9: 274-286

39. Jin Z, McDonald ER, Dicker DT and El Deiry WS (2004) Deficient tumor necrosis factor-related apoptosis-inducing ligand (TRAIL) death receptor transport to the cell surface in human colon cancer cells selected for resistance to TRAIL-induced apoptosis. J. Biol. Chem. 279: 35829-35839

40. Muhlethaler-Mottet A, Bourloud KB, Auderset K, Joseph JM and Gross N (2004) Drug-mediated sensitization to TRAIL-induced apoptosis in caspase-8complemented neuroblastoma cells proceeds via activation of intrinsic and extrinsic pathways and caspase-dependent cleavage of XIAP, Bcl-xL and RIP. Oncogene 23: 5415-5425

41. Kreuz S, Siegmund D, Scheurich $P$ and Wajant $H$ (2001) NF-kappaB inducers upregulate CFLIP, a cycloheximide-sensitive inhibitor of death receptor signaling. Mol. Cell. Biol. 21: 3964-3973

42. Okano H, Shiraki K, Inoue H, Kawakita T, Yamanaka T, Deguchi M, Sugimoto K, Sakai T, Ohmori S, Fujikawa K, Murata K and Nakano T (2003) Cellular FLICE/caspase-8-inhibitory protein as a principal regulator of cell death and survival in human hepatocellular carcinoma. Lab. Invest. 83: 1033-1043

43. Jonsson G, Paulie S and Grandien A (2003) High level of cFLIP correlates with resistance to death receptor-induced apoptosis in bladder carcinoma cells. Anticancer Res 23: 1213-1218
44. Sharp DA, Lawrence DA and Ashkenazi A (2005) Selective knockdown of the long variant of cellular FLICE inhibitory protein augments death receptor-mediated caspase-8 activation and apoptosis. J. Biol. Chem. 280: 19401-19409

45. Weldon CB, Parker AP, Patten D, Elliott S, Tang Y, Frigo DE, Dugan CM, Coakley EL, Butler NN, Clayton JL, Alam J, Curiel TJ, Beckman BS, Jaffe BM and Burow ME (2004) Sensitization of apoptotically-resistant breast carcinoma cells to TNF and TRAIL by inhibition of $\mathrm{p} 38^{\mathrm{MAPK}}$ mitogen-activated protein kinase signaling. Int. J. Oncol. 24: 1473-1480

46. Kim YS, Schwabe RF, Qian T, Lemasters JJ and Brenner DA (2002) TRAIL-mediated apoptosis requires NF-kappaB inhibition and the mitochondrial permeability transition in human hepatoma cells. Hepatology 36: $1498-1508$

47. Vanden Berghe W, Plaisance S, Boone E, De Bosscher K, Schmitz ML, Fiers $W$ and Haegeman $G$ (1998) p38 ${ }^{\mathrm{MAPK}}$ and extracellular signal-regulated kinase mitogen-activated protein kinase pathways are required for nuclear factorkappaB p65 transactivation mediated by tumor necrosis factor. J. Biol. Chem. 273: $3285-3290$

48. Schulze-Osthoff K, Ferrari D, Riehemann K and Wesselborg S (1997) Regulation of NF-kappa B activation by MAP kinase cascades. Immunobiology 198: $35-49$

49. Vermeulen L, De Wilde G, Van Damme $P$, Vanden Berghe $W$ and Haegeman $G$ (2003) Transcriptional activation of the NF-kappaB p65 subunit by mitogenand stress-activated protein kinase-1 (MSK1). EMBO J. 22: 1313-1324

50. Hyer ML, Voelkel-Johnson C, Rubinchik S, Dong J and Norris JS (2000) Intracellular Fas ligand expression causes Fas-mediated apoptosis in human prostate cancer cells resistant to monoclonal antibody-induced apoptosis. Mol. Ther. 2: 348-358

51. Lam N and Sugden B (2003) LMP1, a viral relative of the TNF receptor family, signals principally from intracellular compartments. EMBO J. 22: 3027-3038

Supplementary Information accompanies the paper on Cell Death and Differentiation website (http://www.nature.com/cdd) 